OLEKSANDR STOVPETS,

Odessa National Maritime University (Odesa, Ukraine)

e-mail: a.stovpets@gmail.com,ORCID0000-0001-8001-4223

\title{
SOCIAL-ECOLOGICAL APPROACH TO ANALYSIS OF THE MUNICIPAL WASTE UTILIZATION PROBLEM IN METROPOLIS (THROUGH THE LENS OF PHILOSOPHY AND LAW)
}

The article gives an analysis of different socio-economic, legal-organizational, info-educational, technical and technological aspects of waste treatment, and also the most used models and instruments in the realm of municipal waste management, applicable in the civilized world. A special attention is paid to the main imperfections of the existing waste treatment system in Ukraine and other countries. A comparative method helps to understand the differences, and the crucial problems in waste processing models used in developed and developing countries, in order to make necessary corrections to environmental policy, with implementation of new social-ecological, psychological, legal and economic incentives. A study of the successful waste-reducing and utilization experience of some countries gives a reason to conclude, that their governments and local authorities have created not only the expedient infrastructure for recycling, but also a proper moral-ethical background in the municipal waste management. As we hope, the most significant tools and methods of mentioned environmental policy have been unfolded in this research.

Keywords: consumption philosophy; social ecology; metropolis; eco-friendly consciousness; municipal waste treatment; utilization; recycling.

\section{Introduction}

Hyper-littering from metropolitan areas and the lack of an adequate algorithm of municipal waste management (including waste disposal) is a huge problem of most countries in the modern world. For Ukraine, a generalized picture that can illustrate today's scale of the problem could be described approximately as follows: Ukrainian landfills (both legal and illegal) collectively occupy about $7 \%$ of the whole country's territory! This figure is obviously quite eloquent, thus no further comment is needed on the gravity of the problem.

Mentioned problem is not only a Ukrainian disaster. No doubt, it is a global tendency. With the population growth (and the expansion of urban areas), it's expected that the amount of garbage in the world will inevitably increase, in the fields of production, trade, and consumption.

However, the generation of municipal waste by large cities is only the one side of the problem. Another one is further inefficient management of this waste. And then it really makes sense to talk about the specific legalorganizational, economic, scientific and technological, socio-cultural, infrastructural conditions available in each country. Being united they influence on the total effectiveness of littering reduction.

According to the official information published on March 14,2019 by the Ministry for Development of Communities and Territories of Ukraine, there are almost 54 million $\mathrm{m} 3$ of municipal waste have been generated in Ukraine during 2018 (excluding data from the Autonomous Republic of Crimea and Sevastopol), or, in terms of weight, more than 9 million tons, which have been legally disposed at 6,000 landfills and garbage dumps with a total area of over 9 thousand hectares. $16 \%$ of official landfills do not comply with environmental safety standards. During 2018, only 26 waste sorting lines, 1 waste incineration plant and
3 waste incineration stations were operating in Ukraine. Their total capacity was able to provide processing and utilization for only about $6 \%$ of municipal waste. $2 \%$ of it was incinerated, and about $4 \%$ was taken to refineries and recyclables for extraction of the secondary raw materials (minregion.gov.ua, 2019). The rest of the household waste generated during the year $(94 \%)$ was not recycled and went to landfills scattered across the country.

Here we should state that the statistics presented in this article (both from Ukrainian and EU sources) may be considered relevant with some conventional degree, as they indicate the situation at the end of 2018. The fact is that presently there is no aggregate data for 2019 , as most of such statistics (relevant to the previous year) usually appear in March-April of the current year. However, it is quite evident that the global situation with waste of anthropogenic origin is escalating from year to year. In this point, it becomes clear why there's a rise of the scientific community's attention to the socio-environmental, technological, economic, legal, philosophical and other aspects of management process in respect of the municipal waste produced by mankind.

For this study, an important meaning have some previous researches on issues of: benchmarking the performance of municipal services (Folz, 2004: 209-220), tradeoffs in waste disposal and recycling matters (Offenhuber, and others, 2012: 173-196), a management framework for municipal solid waste systems and food waste prevention (Thyberg, Tonjes, 2015: 133-151), the costs and benefits of packaging waste management systems in Europe (Ferreira, and others, 2017: 773-791), the role of management instruments in the diversion of organic municipal solid waste recycling (Treadwell, Bennett, Clark, 2018: 896-919), a multi-stage optimization approach for sustainable municipal solid waste collection systems in 
urban areas (Mondal, Speier, Weichgrebe, 2019: 536-553), a comparison study of 'motivation-intention-behavior' model on household solid waste sorting (Fan, Yang, Shen, 2019: 442-454), issues of waste-picking in Chinese cities (Wu, Zhang, 2019: 67-74).

\section{Purpose of research}

In the context of all mentioned above, the article's purpose is to make analysis for (existing in Ukraine and the world, most effective) legal-organizational, socialeconomic, info-educational, technological tools used in the field of municipal waste management. Therefore, we will focus on certain aspects of municipal (household) waste disposal and utilization in metropolitan areas.

\section{Methods}

Methodological basis, for our research of municipal waste disposal problems in metropolitan areas, includes the systemic approach, comparative, dialectical and structural-functional methods. Objectively, the study of most environmental problems requires a systemic approach, involving scientific tools of social ecology, urban science, economic studies, sociology, psychology, philosophical anthropology, environmental law, etc. At the same time, studying the features in the implementation of different models of household waste management (especially in cities) compels us to refer to existing regulatory sources, which determine the main preconditions for the development of waste processing technologies, including utilization and recycling. These legal conditions affect the entire spectrum of social-economic relations in the realm of our research. That is why an important part of the methodology used in this study refers to formal-juridical and legal-comparative methods.

In particular, the application of the latter two methods implies obvious need to consider some key legislation acts, among which are the Laws of Ukraine: "On Environmental Protection" (The Law of Ukraine № 1264XII, 1991), "On Waste" (The Law of Ukraine № 187/98-BP, 1998), "On the National Program for the treatment with toxic waste" (The Law of Ukraine № 1947-III, 2000). Besides, Ukraine has joined the UN Framework Convention on Climate Change (The Law of Ukraine № 435/ 96-BP, 1996), and it's also expected that the Law of Ukraine "On the principles of monitoring, reporting and verification of greenhouse gas emissions" (The Law of Ukraine № 377-IX, 2019) will come into force on January 1, 2021, aiming at fulfilling Ukraine's obligations according to the Association Agreement with EU (The Law of Ukraine № 1678-VII, 2014).

\section{Results and Discussion}

A key role for the environment protection plays the country-specific waste management model - a set of activities aimed at preventing the generation of waste, its collection, transportation, sorting, storage, treatment, processing, deactivation, safe disposal, utilization, recycling, landfill burial, and including monitoring of these operations and supervision of the disposal sites themselves. All these operations are closely connected and mutually determined.

For better visualization, let's present a brief overview of the key terminology used in Ukrainian waste management system, in the analytical table below:

\begin{tabular}{|c|c|c|}
\hline \multicolumn{3}{|c|}{ WASTE } \\
\hline \multicolumn{3}{|c|}{$\begin{array}{l}\text { Wastes - any substances, materials and objects generated in the process of production or consumption, as well } \\
\text { as goods (products) that have completely or partially lost their consumer qualities and have no further use at the } \\
\text { place of their formation, and which have to be disposed by their owner (by his own will or according to the } \\
\text { legislation). Both household (municipal) and industrial waste can be either hazardous (including toxic) or } \\
\text { relatively safe. }\end{array}$} \\
\hline \multicolumn{2}{|c|}{$\begin{array}{l}\text { Municipal waste - wastes (solid, liquid, house-repairing, extra-large, } \\
\text { etc.) generated in the course of human life and activity in residential and } \\
\text { non-residential buildings, and not used at their place of accumulation }\end{array}$} & $\begin{array}{l}\text { Industrial waste - any waste which } \\
\text { was generated in processes } \\
\text { of production activity of enterprises }\end{array}$ \\
\hline \multicolumn{3}{|c|}{ WASTE treatment OPERATIONS } \\
\hline $\begin{array}{l}\text { "Non-alternative " } \\
\text { (those being performed in any case, but in different } \\
\text { volume - depending on the situation) }\end{array}$ & \multicolumn{2}{|c|}{$\begin{array}{c}\text { "Alternative " } \\
\text { (desirable from economical and / or } \\
\text { social-ecological standpoints) }\end{array}$} \\
\hline $\begin{array}{l}\text { - collecting } \\
\text { - transportation } \\
\text { - sorting } \\
\text { - storage } \\
\text { - disposal } \\
\text { - removal } \\
\text { - neutralization } \\
\text { - landfilling }\end{array}$ & \multicolumn{2}{|c|}{$\begin{array}{l}\text { - reduction of waste generation } \\
\text { - processing, including different } \\
\text { forms of utilization: } \\
\text {. recycling } \\
\text { - regeneration } \\
\text { - recuperation } \\
\text {. incineration }\end{array}$} \\
\hline \multicolumn{3}{|c|}{ official supervision by the state, and informal control - of civil society } \\
\hline
\end{tabular}

The most rational and "eco-friendly" option for waste management is utilization, which is structurally related to the waste treatment process, and may include a recycling processes. There is also a need for some terminological clarification.

Clause 1 of the Law of Ukraine "On Waste" implies that utilization is a kind of a process when the waste is used either as secondary raw material or as energy resource. Certainly, the word "utilization" has Latin roots ("utilis" means "useful"). From this definition, it can be concluded that not only recycling processes and the whole use of waste as secondary raw materials, but also incineration operations (waste burning that leads to a positive energy effect) should be considered as utilization.

There's an opinion (Angrick, Burger, Lehmann, 2015: 114), waste processing differs from utilization. The purpose of processing is to convert waste into secondary raw materials, energy or products with certain consumer properties. Along with that, the processing of waste may or may not include their transformation - activities aimed at changing the physical, chemical or biological state of waste, to enable further treatment operations with it. 
Many materials, like glass, paper, aluminum, asphalt, iron, cloth, organic substances (sources of numerous harmful bacteria and even viruses), and various types of plastic may be recovered from waste. In some cases, waste treatment operations are technically inappropriate, economically unprofitable due to the excessive consumption of material, energy, transport, financial, human resources. Moreover, waste processing can also cause new waste.

The waste utilization itself can be performed in different ways. In the most general sense, "utilization" means the use of waste in production of new goods (products), in the provision of services, in any possible reuse of waste. However, when it comes to the re-use of waste for its intended purpose, this type of utilization is called "recycling". If waste is returned to the production cycle after necessary preparation, then it is called "regeneration". And if the extraction of useful components from the waste takes place and these components may be re-used in appropriate technological process, then the term "recuperation" is applicable (Pellow, Weinberg, Schnaiberg, 2000: 36).

While designing any modern product, its ability to be utilized (and safely disposed) must be taken into account. This potential recyclability (or direct re-use) is calculated on the basis set of indicators, which reflect the efficiency degree of utilization of the product after its decommissioning, as well as the waste generated during the manufacturing and use of the product itself (Pellow, Park, 2004: 188-189).

Thus, "utilization" and "processing" (waste treatment) overlap. For instance, the processing of waste may involve their utilization - in the meaning of use more than once. Utilization, in its turn, may involve preliminary treatment of waste where it is technically possible, technologically feasible, or required by law. On the other hand, utilization doesn't imply any treatment, where the waste can be used in the manufacturing process directly, without processing or preliminary treatment.

Waste processing also should not be equated with recycling. The term "recycling" is used to define the practice of returning waste to the processes of technogenesis. In other words, recycling is a process, while the waste processing is an activity consisting of different processes. In this sense, recycling is one of the elements of waste utilizing (i.e. utilization), and the latter is a component of waste treatment, i.e. waste processing (Nielsen, 2011: 83). For example, waste recycling may be performed by the second use of waste for the same purpose (e.g. using bottles made of glass for their intended purpose, after appropriate processing), or by returning of waste components into the manufacturing cycle, after their extraction (e.g. transformation of metal cans into the raw material for steel industry, waste paper - in the production of paper and cardboard, and so on).

A clear understanding of the content and differences of the waste treatment concepts (mentioned above) has a paramount importance. It may decide: which of the existing models of waste disposal and utilization will be considered as optimal in a certain country. Nevertheless, the modern intensification of scientific and technological progress, along with anthropogenic impacts to the environment, lead to emerging of existential problems: ecological, socialeconomic, even ideological and geopolitical. Conflict relationships - with Nature, people among themselves (at the level of social groups, nations, countries) - threaten to fragile harmony in the development of complex systems like the Biosphere and the Human society. It also sharpens the issues of survival in conditions of limited resources, and naturally leads to increase of inter-social tensions.

Crises of anthropogenic origin may be estimated as a reversible state of an ecosystem whereas man is an active component, and is still capable to reduce the level and consequences of our environmental delinquencies. However, we definitely shouldn't neglect the probability for realization of the well-known dialectical principle of "the transition of quantitative changes into qualitative ones", when (closely to our problematic) all those constantly accumulated common human errors and misdeeds against Nature could suddenly be transformed into unbalanced state. In this case, catastrophic consequences for humanity are not excluded.

There's a reasonable idea (Dadd-Redalia, 1994: 201) that global environmental disorders, which are manifested in changes of environmental characteristics across the globe, are unlikely to be rehabilitated. But local environmental violations (most often associated with excessive levels of waste pollution due to the activities of several regional facilities) are fully regulated through various administrative measures and technical-economic instruments. E.g. improving the technological process of waste treatment at a particular enterprise with the production of secondary raw materials, optimizing procedures for disposal of waste outside of manufacture facility, waste processing and utilization using environmental logistics approaches.

In mentioned context, there is a sense in reflecting on which models of waste management are the most favorable and optimal, taking into account all the knowledge about our world and contemporary understanding how it functions. Talking about all kinds of waste seems to us unproductive for the article format. So we'd better limit this study by more careful look into the so-called municipal solid waste. Because most of us are not directly related to the generation of industrial waste, but everyone produce municipal (household) waste, that's for sure. It's also known as "trash" or "garbage". And the structure of this kind of waste differs individually - depending on the country of residence, social class, mentality, personal cultural level, habits, professional and confessional affiliation, moral and ethical values, life experience and the worldview, and other factors.

In European terminology, solid household waste is often called "municipal waste". An explanation is that historically, in many European cities, local authorities had been responsible for collecting, transporting and disposing of garbage. However, nowadays, in developed countries a significant part of municipal waste is collected and processed by private enterprises. Most of them also deal with the processing of industrial waste.

In terms of price, the municipal waste market in developing countries is estimated at about $\$ 120$ billion. But the largest real volume in this segment today belongs to markets of the USA ( $\$ 46.5$ billion), Europe (EU countries together with Norway and Switzerland, about $\$ 36$ billion) and Japan (over $\$ 30.5$ billion). Simultaneously, in the world practice nowadays the overwhelming amount of municipal solid waste is still being exported to landfills. In the postSoviet countries, generally about $97 \%$ of household waste is being disposed in landfills; in the United States it's about $73 \%$; most of EU countries, Canada, and many others do the same (recyclers.com.ua, 2017). But the most reasonable question is: what part of all these waste, placed there for storage, will remain not recycled, and how much will be exported for processing from landfills to special enterprises?

It's obvious that the disposal of household waste at 
landfills should be considered as a forced measure; it's inevitable but only temporary solution, which contradicts conceptually the philosophy of "eco-friendly thinking", as well as modern principles of environmental logistics. The thing is that valid sanitary standards of most civilized countries require a gradual expansion of the distance between landfills and metropolitan areas. Therefore, the expenses (first to municipal services, and then to consumers) for the transportation of garbage are gradually rising. Not to mention the inefficient use of land, when there is another enlargement of the waste storage area, especially in countries, which have no infrastructure for processing, utilization, recycling of municipal and other waste.

So the organization of systemic industrial recycling seems the only crucial way to solve the municipal waste problem in metropolis. Today the most widespread wastetreatment technologies are: heat processing (mainly incineration), biothermal aerobic composting (to produce biofuels), anaerobic digestion (or fermentation, to produce biogas), sorting (in order to extract valuable components for the secondary use, and dangerous components that must be deactivated).

Each of these processing methods has its advantages, complexities and disadvantages. One of the most debatable issues is the practice of industrial incineration of garbage. On the one hand, municipal waste incineration can reduce its original mass by $70-85 \%$ and shorten its volume by $90-95 \%$, while also eliminating the organic compound contained in the incinerated waste. Garbage combustion heat is also used for energy purposes - in the production of thermal and electrical energy, as the calorific value of solid waste is comparable to some low-grade fuels (peat, brown coal). Thus, incineration gives a possibility to cover partially the energy needs of agglomerations.

On the other hand, incineration is not as productive as recycling of waste into secondary raw materials - a process of extracting material resources, which are possible and expedient to be reused in a new manufacturing cycle. Unfortunately, not any waste can be recycled, and then it can be reused at least through thermal conversion to energy. In this case, it will not be secondary raw materials, but secondary energy resources.

In European countries, an average of $20-25 \%$ of municipal waste is recycled by incineration method. However, this figure may differ significantly across EU countries. For example, in Denmark about $80 \%$ of all household waste is recycled through incineration, in Sweden and Finland this figure is $50-60 \%$, in Austria, Germany, France, Italy $20-40 \%$. Sweden is the leader in the implementation of the so-called "WtE" (Waste to Energy) concept, i.e. the energetic utilizing of waste via incineration. Swedish wasteincinerating plants generate approximately $16 \%$ of all thermal energy (heat) for the country, and up to $1.4 \%$ of all electricity. In total, about 400 waste-incinerating powerplants operate in Europe. The vast majority of these plants are equipped with the necessary filtration systems (EEA, 2016).

Being one of the models of household waste management, incineration is widely used in countries with a temperate climate and few windy days throughout the year. Also, combustion of municipal waste is objectively widespread in countries with small territories and high density population (e.g. Japan). In some industrially developed European countries, thermal processing of waste is almost inevitable way of treatment, as local environmental laws prohibit the landfills disposal of those waste, in which the organic content exceeds $5 \%$.
Finally, the most progressive and environmentallyfriendly contemporary model of municipal waste management is integrated recycling. The main problematic of the industrial processing of municipal waste is its morphological complexity. Still there is no consensus which one among the existing waste-processing technologies is the most rational, considering how many materials today's products consist of. That is why the technology of selective collection of different components from urban garbage has become applicable, with separation of glass, wastepaper, polymeric materials, metal cans, plastic bottles, batteries, food waste, etc. Such a separation for collected municipal waste is made into special containers that are located in different places, but as close as possible to the wastegenerating sources. Even glassware made of transparent or dark glass ought to be collected in different containers. In addition, there is a system of collecting-points, including vending machines for receiving metal cans on a fee basis.

In most European countries, preliminary sorting of household waste is carried out by the population themselves, using specially marked bags and containers. Then the sorted waste from separate containers is much easier to collect and recycle. In this regard, psychological aspects of the whole process are extremely meaningful. Conscientious attitude of the population to primary sorting of their waste depends on the ethical and ideological position of people, and on the emotional and psychological motivation.

One of the powerful tools available to local authorities is the combination of the economic benefits principle due to the rational waste treatment, and such a symbolic, but highly significant effect of people's involvement and contribution into regional environmental well-being. And today there are countries where about $20 \%$ of the fuel used in the national transport sector has a renewable nature (biogas, biodiesel, bioethanol). Many municipalities and cities that have established their own production of biofuels are trying to visualize their success, to advertise it in a special way, e.g. by labeling or painting the public transport running on such fuels. That gives an important psychological effect: citizens see it and feel their involvement (on the principle "if we sort household waste, then we do not have landfills, and our city has such a wonderful buses"). In this manner, people realize a real ability to influence upon their own ecological safety, which comes as a direct result of the "eco-friendly" thinking, supported by appropriate behavior.

Returning to the technological aspects of municipal waste treatment in metropolitan areas, it should be noted that urban waste contains biomass, a priority renewable energy source. Therefore, along with incineration of waste that is no longer recyclable, another rational method of municipal waste processing is a biological digestion, which provides with compost and biofuels.

Biotechnological process of organic waste composting proceeds with the participation of mesophilic and thermophilic microorganisms under aerobic conditions (with air access). It helps to support the natural circulation of substances. Alternative fuels, as biogas, are produced on biomass waste basis, by the anaerobic process of methane fermentation. That is a process of biodegradation of organic substances with the release of free methane (Jansson, 2019).

Undoubtedly, the amount of municipal waste used as secondary material resources is expedient to increase, both from environmental and economical standpoints. However, the difficulties of such measures are conditioned by a number of objective reasons. One of them is the significant difference between countries in terms of muni- 
cipal waste generated per capita (from $272 \mathrm{~kg}$ in Romania to $766 \mathrm{~kg}$ in Denmark - based on "Eurostat", EU Statistical Office, in evaluation of 2018). This is also explained by the different consumption patterns and various approaches to collecting statistical information (some countries may include waste generated by small businesses and government agencies, but exclude industrial waste in any case).

Considering the pan-European average of municipal waste generated per capita in 2018 across the EU countries (and this is the most recent available data processed and published by "Eurostat"), we see that in the EU during 2018 the average of household waste amount per capita was $489 \mathrm{~kg}$ (Municipal waste statistics, 2018). In Ukraine, this figure is around $300 \mathrm{~kg}$ per capita every year. At the same time, if we analyze what part of those household waste was recycled (in the EU as a whole, and in Ukraine), then we see, in the EU (Eurostat, 2018) this overall figure for 2018 was $47.1 \%$. And in Ukraine only $4 \%$, which is critically small. It has a direct consequence as the extremely high level of contamination of Ukrainian territory.

"Eurostat" official website states that municipal waste treatment involves such activities as processing for secondary raw materials, recycling, composting and anaerobic fermentation. Waste incineration (energy-making also) is not considered as a recycling, and its share in EU countries is accounted separately. As for the indicators of household waste utilization in particular EU countries, statistics from "Eurostat" allow us to see the dynamics of waste processing in each EU country, year by year. Thus, if we compare how waste treatment practices have been progressing in 2017 and 2018, for example, in Germany, this indicator there is one of the highest in Europe: $67.2 \%$ (2017) and $67.3 \%$ (2018) of the total domestic municipal waste were recycled (into raw materials, compost, anaerobically extracted biogas), and the rest was burned. In Austria, these figures are almost the same. But in other EU countries, unfortunately, the efficiency of recycling is lower: $47.8 \%$ (2017) and $49.8 \%$ (2018) in Italy; $33.8 \%$ (2017) and $34.3 \%$ (2018) in Poland (Eurostat, 2018).

It's obvious that a huge part of all household, industrial and other waste is valuable raw materials, which could and should be recycled in various sectors of the economy. Against this background, the harmonization of activities of all the actors (manufacturing enterprises, waste-processing and incineration plants, compost farms and other important units) of the waste management should be reconsidered today from a holistic point of view.

Presently, there is going a global reorientation that implies the renewal of integrated waste management concepts, one of which is the so-called $3 R$ program (Reduce, Reuse, Recycle): reducing the production intensity of household waste, their secondary use and recycling, selective waste collection for better utilization perspectives (Nongpluh, Noronha, 2013). This methodological approach to waste recycling is likely to contribute to resourceproblem solving for future generations, reducing the amount of landfill sites, and many related environmental problems, so relevant to Ukraine and the absolute majority of countries.

\section{Conclusions}

The analysis of technical and technological, socioeconomic, legal-organizational, info-educational tools (which are the most used in the realm of municipal waste management, in Ukraine and the rest of the civilized world) allows to highlight the main imperfections of the existing system for waste treatment, and to formulate certain ideas.
Their implementation, as we believe, would contribute to the improvement of a range of acute problems in the researched field.

The position of human in the biosphere, the status of Homo sapiens in the planetary ecosystem, imposes on mankind an obligation to self-restrain. This applies both to our aggressive technological expansion (sometimes spontaneous, without calculating all the important consequences for the biosphere), and to irrational models of consumerism (when the interests of tomorrow's generations well-being are overshadowed by the immediate economic imperatives). In other words, there is a universal humanitarian need for self-limitation in producing and consuming things, and this need has obviously to be recognized both in the collective social space and at the individual level.

Nevertheless, the global challenge is the fact (and it will remain at least for a nearest decades) that presently only a few countries in the world have achieved real success in the waste utilizing and recycling. But even among these countries, some of them are simultaneously the largest waste-producers. There is a tendency that the life standard raising in any country (in particular, expanding of the middle class, with the following rising of domestic demand and the purchasing ability of the population) naturally leads to increasing generation of municipal waste that is growing intensively in these countries.

At the same moment, a lot of developed countries being concerned about the waste surfeit at their own landfills and trying to reduce it (especially in the situation of the lack of utilizing infrastructure) are looking for new landfills in less developed countries where prospects for safe treatment, utilization, and recycling of imported waste are principally not available. But, the ecosystem of the Earth is whole, unified, and does not obey to political-administrative differentiation. Consequently, due to the waste export policy - from more prosperous countries to those, which practice waste disposal without any processing on their territories, on a paid basis - the entire global ecosystem is suffering (and all the humanity as inseparable part of the ecosystem).

In the societies of the most developed countries, where the general awareness of the negative anthropogenic impacts on the environment, and the individual level of ecological consciousness of most people are quite high, there is a permanent discussion about the safety and effectiveness of technological models for waste management (should it be recycling into raw materials, or composting, or anaerobic digestion, or energy-efficient combustion or, in some cases, simple incineration). Anyway, it is important to remember that waste is always a danger - regardless if we burn it to reduce its volume and weight, or it is heat-treated to be decontaminated or to gain thermal energy, or it is utilized otherwise. But the worst thing to do with waste is to leave it at the landfill for a long time or for permanent storage. Because, in any case, this will lead to methane emissions into the air, poisoning of land and groundwater, epidemiological threats, and other destructive results.

A primary step, indispensable and win-win for any country - whether it's developed or not, large or small by territory or population - is to perform an active infoeducational work, with a key message: to generate less garbage, as little household waste as possible! The society should be finally convinced that each of us can contribute to the reduction of municipal waste: if we minimize the use of plastic bags and disposable tableware, replacing them with more "eco-friendly" analogues; if we optimize the structure of our consumption, in particular, the use of 
personal transport; if we shall try first to repair things, instead of throwing them away at once and buying new ones; if we will behave responsible in sorting our own waste.

At the second position, by its role for ecology (after the mentioned ideological, info-educational work), it should be placed the very practice of municipal waste sorting and recycling, and only then - the practice of its incineration. Here it is worth emphasizing that the incineration of household waste, in compliance with all established standards, is much more environmentally friendly than any landfill.

One of the main principles of the waste management system is to collect and sort the garbage at the earliest possible stage, preferable right at the place of its generation. In developed countries, one of the most important achievements of governments and municipal authorities in the waste treatment is that they have managed to cultivate in their citizens the creed about necessity for self-sorting of their own household waste. Along with that the local authority in such countries has created a proper moralethical background in the municipal waste management, but also the financial incentives are used there. Households, which sort their garbage (including separate collecting of food waste that makes it compostable), pay substantially less for garbage disposal comparable to those who throw out mixed garbage.

It is important to understand the key role of a private recycling business in the municipal waste processing. This is especially true for metropolitan areas, usually overflowed with garbage (and possibilities of its utilizing). In such conditions, various private companies are competing in the recycling market, expanding the range of their specific services and improving utilization models. In most countries that have succeeded in the recycling of household waste, private companies had become the driver of this progress. Understood, they have an apparent interest in processing as much waste as possible, with the extraction of the maximum amount of recycling-suitable components, for resale and subsequent utilization. Organic waste also becomes a raw material for biofuels.

At the same time, the state and municipalities retain control and supervising functions over the activities of private waste-collecting companies. Usually their scheme of interaction looks like this: the parliamentarians set general legislative guidelines, whereas the profile executive bodies regulate the order of treatment for different types of waste, taking into account the specificity of a metropolis, and the region as a whole. Environmental experts are always enrolled in all the stages. The regional municipalities should be guided by the national standards and regulations, but they can choose the methods and options for achieving the result at their own discretion.

An important methodical appliance of local authorities should be the combination, on the one hand, of the principle of economic benefits from the rational waste management in metropolis, and, on the other, of that symbolic (but highly significant) effect of people's involvement in regional environmental well-being. Due to the above mentioned psychological and info-educational techniques, people feel a real ability to make influence upon their own environmental safety, which becomes a direct result of the so-called eco-friendly thinking, coupled with appropriate behavior.

\section{REFERENCES}

Angrick, M., Burger, A., Lehmann, H. (2015). Factor X: resource - designing the recycling society. Dordrecht: Springer, 290 pages. P. 114
Association Agreement between the European Union and the European Atomic Energy Community and their Member States, of the one part, and Ukraine, of the other part: International treaty signed on 27.06.2014. Agreement ratified by the Law of Ukraine № 1678-VII on 16.09.2014. The Official Bulletin of Ukraine. 26.09.2014. № 75, vol. 1, p. 83, cl. 2125 (valid edition on 30.11.2015). URL: https://zakon.rada.gov.ua/laws/show/en/984_011

Dadd-Redalia, D. (1994). Sustaining the Earth: choosing consumer products that are safe for you, your family, and the Earth. New York: Hearst Books, 352 pages. P. 201.

Fan, B., Yang, W. T., Shen, X. C. (2019). A comparison study of 'motivation-intention-behavior' model on household solid waste sorting in China and Singapore. Journal of Cleaner Production, 211, 442-454. DOI: https://doi.org/10.1016/j.jclepro.2018.11.168

Ferreira, S., Cabral, M., da Cruz, N. F., Simoes, P., Marques, R. C. (2017). The costs and benefits of packaging waste management systems in Europe: the perspective of local authorities. Journal of Environmental Planning and Management, 60 (5), 773-791. DOI: https://doi.org/10.1080/09640568.2016.1181609

Folz, D. H. (2004). Service quality and benchmarking the performance of municipal services. Public Administration Review, 64 (2), 209-220. DOI: https://doi.org/10.1111/j.1540-6210.2004.00362.x

Jansson, A. T., Patinvoh, R. J., Sárvári Horváth, I., Taherzadeh, M.J. (2019). Dry Anaerobic Digestion of Food and Paper Industry Wastes at Different Solid Contents. Fermentation, 2019, 5(2), 40. DOI: https://doi.org/10.3390/fermentation5020040

Mondal, M. M., Speier, C. J., Weichgrebe, D. (2019). Multistage optimization approach for sustainable municipal solid waste collection systems in urban areas of Asia's newly industrialized countries. Environmental Management, 63 (4), 536-553. DOI: https://doi.org/10.1007/s00267-018-1130-6

Municipal waste management across European countries (2016). European Environmental Agency (EEA), 14 November 2016. URL: https://www.eea.europa.eu/themes/waste/wastemanagement/municipal-waste-management-across-europeancountries

Municipal waste statistics 2018 (Municipal waste generated, 2005 and 2018, kg per capita). EUROSTAT, Data extracted in June 2019. URL: https://ec.europa.eu/eurostat/statistics-explained/ index.php/Municipal_waste_statistics

Nielsen, C. J. (2011). Recycling: processes, costs, and benefits. New York: Nova Science Publishers, 426 pages. P. 83.

Nongpluh, Y. S., Noronha, G. C. (2013). Know all about: reduce, reuse, recycle. New Delhi: The Energy and Resource Institute, $140 \mathrm{p}$.

Offenhuber, D., Lee, D., Wolf, M. I., Phithakkitnukoon, S., Biderman, A., Ratti, C. (2012). Putting Matter in Place Measuring Tradeoffs in Waste Disposal and Recycling. Journal of the American Planning Association, 78 (2), 173-196. DOI: https:// doi.org/10.1080/01944363.2012.677120

On Environmental Protection: The Law of Ukraine № 1264-XII, 25.06.1991. (1991). Vidomosti Verkhovnoyi Rady Ukrainy. № 41, cl. 546 (valid edition on 18.12.2019). URL: https://zakon.rada.gov.ua/laws/show/1264-12

On the National Program for the treatment with toxic waste: The Law of Ukraine № 1947-III, 14.09.2000. (2000). Vidomosti Verkhovnoyi Rady Ukrainy. № 44, cl. 374 (valid edition on 14.09.2000). URL: https://zakon.rada.gov.ua/laws/show/1947-14

On the principles of monitoring, reporting and verification of greenhouse gas emissions: The Law of Ukraine № 377-IX, 12.12.2019. The Law will come into force on January $1,2021$. URL: https://zakon.rada.gov.ua/laws/show/377-20

On Waste: The Law of Ukraine № 187/98-BP, 05.03.1998. (1998). Vidomosti Verkhovnoyi Rady Ukrainy. № 36-37, cl. 242 (valid edition on 01.05.2019). URL: https://zakon.rada.gov.ua/laws/ show/187/98-\%D0\%B2\%D1\%80

Pellow, D. N., Park, L. S.-H. (2004). Garbage Wars: The Struggle for Environmental Justice in Chicago. Cambridge (MA): MIT Press, 256 pages. P. 188-189. 
Pellow, D. N., Weinberg, A., Schnaiberg, A. (2000). Urban Recycling and the search for sustainable community development. Princeton: Princeton University Press, 232 pages. P. 36.

Recycling rate of municipal waste (\% recycled of total municipal waste generated) in 2018. EUROSTAT, 2018. URL: https:/ lec.europa.eu/eurostat/tgm/table.do?tab=table\&init=1\&language$=e n \&$ pcode $=$ sdg_11_60\&plugin $=1$

State of the domestic waste management industry in Ukraine for 2018. (2019). The official web-portal of the Ministry for Development of Communities and Territories of Ukraine, 14.03.2019. URL: http://www.minregion.gov.ua/napryamkidiyalnosti/zhkh/terretory/stan-sferi-povodzhennya-z-pobutovimividhodami-v-ukrayini-za-2018-rik/

The UN Framework Convention on Climate Change (New York, May 9, 1992): ratified by the Law of Ukraine № 435/96-BP, 29.10.1996. (1996). Vidomosti Verkhovnoyi Rady Ukrainy. № 50, cl. 277. URL: https://zakon.rada.gov.ua/laws/show/995_044

Thyberg, K. L., Tonjes, D. J. (2015). A Management Framework for Municipal Solid Waste Systems and Its Application to Food Waste Prevention. Systems, 3 (3), 133-151. DOI: https://doi.org/ 10.3390/systems3030133

Treadwell, M. L., Bennett, E. M., Clark, O. G. (2018). The role of management instruments in the diversion of organic municipal solid waste and phosphorus recycling. Facets, 3, 896-919. DOI: https://doi.org/10.1139/facets-2018-0005

Waste Recycling in developed countries (2017). RECYCLERS.COM.UA, 27.04.2017. URL: https://recyclers.com.ua/ua/ blog/novosti-so-vsego-mira/pererabotka-othodov-v-razvityihstranah-mira

Wu, K. M., Zhang, J. Y. (2019). Living with Waste Becoming "Free" As Waste Pickers in Chinese Cities. China Perspectives, 2019-2, 67-74. DOI: https://doi.org/10.4000/chinaperspectives.9184

\section{LIST OF REFERENCE LINKS}

Закон України про відходи. Відомості Верховної Ради України (ВBP), 1998, № 36-37, ст.242. URL: https://zakon.rada.gov.ua/laws/show/187/98-\%D0\%B2\%D1\%80

Закон України про Загальнодержавну програму поводження з токсичними відходами. Відомості Верховної Ради України (ВВP), 2000, N 44, ст.374. URL: https://zakon.rada.gov.ua/ laws/show/1947-14

Закон України про охорону навколишнього природного середовища. Відомості Верховної Ради України (ВВР), 1991, № 41, ст.546. URL: https://zakon.rada.gov.ua/laws/show/126412

Переработка отходов в развитых странах мира. RECYCLERS.COM.UA, 27.04.2017. URL: https://recyclers.com.ua/ua/ blog/novosti-so-vsego-mira/pererabotka-othodov-v-razvityihstranah-mira

Рамкова конвенція Організації Об'єднаних Націй про зміну клімату (Конвенцію ратифіковано Законом N 435/96-ВР від 29.10.96). Відомості Верховної Ради України (ВВР), 1996, N 50, ст.277. URL: https://zakon.rada.gov.ua/laws/show/995 044

Стан сфери поводження з побутовими відходами в Україні за 2018 рік. Міністерство розвитку громад та територій України. 14.03.2019. URL: http://www.minregion.gov.ua/ napryamki-diyalnosti/zhkh/terretory/stan-sferi-povodzhennya-zpobutovimi-vidhodami-v-ukrayini-za-2018-rik/

Угода про асоціацію між Європейським Союзом та Європейським співтовариством з атомної енергії та їх державами-членами, з одного боку, та Україною, з іншої частини: Міжнародний договір, підписаний 27.06.2014. Угода, ратифікована Законом України № 1678-VII від 16.09.2014. Офріційний вісник України. 26.09.2014. № 75, vol. 1, p. 83, cl. 2125 URL: https:// zakon.rada.gov.ua/laws/show/en/984_011

Angrick M., Burger A., Lehmann H. Factor X: re-source designing the recycling society. Dordrecht: Springer, 2015. 290 pages. P. 114
Dadd-Redalia D. Sustaining the Earth: choosing consumer products that are safe for you, your family, and the Earth. New York: Hearst Books, 1994. 352 pages. P. 201.

Fan B., Yang W. T., Shen X. C. A comparison study of 'motivation-intention-behavior' model on household solid waste sorting in China and Singapore. Journal of Cleaner Production. 2019. 211. Pp. 442-454. DOI: https://doi.org/10.1016/j.jclepro.2018.11.168

Ferreira S., Cabral M., da Cruz N. F., Simoes P., Marques R. C. The costs and benefits of packaging waste management systems in Europe: the perspective of local authorities. Journal of Environmental Planning and Management. 2017. 60 (5). Pp. 773-791. DOI: https://doi.org/10.1080/09640568.2016.1181609

Folz D. H. Service quality and benchmarking the performance of municipal services. Public Administration Review. 2004. 64 (2). Pp. 209-220. DOI: https://doi.org/10.1111/j.1540-6210.2004.00362.x

Jansson A. T., Patinvoh R. J., Sárvári Horváth I., Taherzadeh M.J. Dry Anaerobic Digestion of Food and Paper Industry Wastes at Different Solid Contents. Fermentation. 2019. 5(2). P. 40. DOI: https://doi.org/10.3390/fermentation5020040

Mondal M. M., Speier C. J., Weichgrebe D. Multi-stage optimization approach for sustainable municipal solid waste collection systems in urban areas of Asia's newly industrialized countries. Environmental Management. 2019. 63 (4). Pp. 536-553. DOI: https:/ /doi.org/10.1007/s00267-018-1130-6

Municipal waste management across European countries (2016). European Environmental Agency (EEA), 14 November 2016. URL: https://www.eea.europa.eu/themes/waste/waste-management/municipal-waste-management-across-european-countries

Municipal waste statistics 2018 (Municipal waste generated, 2005 and 2018, kg per capita). EUROSTAT, Data extracted in June 2019. URL: https://ec.europa.eu/eurostat/statistics-explained/ index.php/Municipal_waste_statistics

Nielsen C. J. Recycling: processes, costs, and benefits. New York: Nova Science Publishers, 2011. 426 pages. P. 83.

Nongpluh Y. S., Noronha G. C. Know all about: reduce, reuse, recycle. New Delhi: The Energy and Resource Institute, 2013. $140 \mathrm{p}$.

Offenhuber D., Lee D., Wolf M. I., Phithakkitnukoon S., Biderman A., Ratti C. Putting Matter in Place Measuring Tradeoffs in Waste Disposal and Recycling. Journal of the American Planning Association. 2012. 78 (2). Pp. 173-196. DOI: https://doi.org/ $10.1080 / 01944363.2012 .677120$

On the principles of monitoring, reporting and verification of greenhouse gas emissions: The Law of Ukraine № 377-IX, 12.12.2019. The Law will come into force on January 1, 2021. URL: https://zakon.rada.gov.ua/laws/show/377-20

Pellow D. N., Park L. S.-H. Garbage Wars: The Struggle for Environmental Justice in Chicago. Cambridge (MA): MIT Press, 2004. 256 pages. P. 188-189.

Pellow D. N., Weinberg A., Schnaiberg A. Urban Recycling and the search for sustainable community development. Princeton: Princeton University Press, 2000. 232 pages. P. 36.

Recycling rate of municipal waste (\% recycled of total municipal waste generated) in 2018. EUROSTAT, 2018. URL: https://ec.europa.eu/eurostat/tgm/table. do?tab=table\&init=1\&language=en\&pcode=sdg_11_60\&plugin=1

Thyberg K. L., Tonjes D. J. A Management Framework for Municipal Solid Waste Systems and Its Application to Food Waste Prevention. Systems. 2015. 3 (3). Pp. 133-151. DOI: https://doi.org/ 10.3390/systems 3030133

Treadwell M. L., Bennett E. M., Clark O. G. The role of management instruments in the diversion of organic municipal solid waste and phosphorus recycling. Facets. 2018. 3. Pp. 896919. DOI: https://doi.org/10.1139/facets-2018-0005

Wu K. M., Zhang J. Y. Living with Waste Becoming "Free" As Waste Pickers in Chinese Cities. China Perspectives. 2019-2. Pp. 67-74. DOI: https://doi.org/10.4000/chinaperspectives.9184 
Олександр Стовпець,

Одеський національний морський університет (м. Одеса, Украӥна)

e-mail: a.stovpets@gmail.com,ORCID 0000-0001-8001-4223

\section{СОЦІАЛЬНО-ЕКОЛОГІЧНИЙПІДХІД ДО АНАЛІЗУ ПРОБЛЕМИ УТИЛІЗАЦІї ПОБУТОВИХ ВІДХОДІВ У МЕГАПОЛІСАХ (КРІЗЬ ПРИЗМУ ФІЛОСОФІЇ І ПРАВА)}

У статті аналізуються уживані в Україні та світі організаційно-правові, соціально-економічні, інформаційнопросвітницькі, технологічні засоби у сфері поводження із побутовими (муніципальними) відходами, які продукуються у мегаполісах. Вивчаються термінологічні відмінності між такими процесами й операціями, як перероблення відходів, утилізація, рециклінґ, регенерація, рекуперація. Робиться акцент на тому, що різні етапи і форми поводження із побутовими відходами (включаючи їхнє збирання, перевезення, сортування, зберігання, оброблення, перероблення, утилізацію, видалення, знешкодження, захоронення) є взаємно детермінованими. Звертається увага на те, що, хоча побутові відходи продукує кожна людина, однак структура цих відходів у кожної людини відрізняється - залежно від країни проживання, соціального класу, менталітету, персонального культурного рівня, звичок, професійної та конфесійної приналежності, морально-етичних установок й світоглядних орієнтирів, рівня інформованості та екологічної свідомості тощо. Спостерігається тенденція, що в країнах із розвиненим громадянським суспільством зазвичай впроваджуються більш раціональні й "екодружні" моделі поводження з відходами. Способом системного вирішення проблеми муніципальних відходів у мегаполісах є організація їхньої промислової переробки. Найбільш оптимальними технологіями поводження із побутовими відходами на сьогодні є: термічне перероблення (переважно це т.зв. енергетичне спалювання, у деяких випадках - проста інсінерація), біотермічне аеробне компостування (із одержанням біопалива), анаеробна ферментація (з отриманням біогазу), сортування, із видаленням цінних компонентів для вторинного використання, шкідливих компонентів - для подальшої дезактивації, решти речовин - для застосування до них найбільш технічно-, економічно- й екологічно-обґрунтованих операцій. Не менш важливими за технологічні й соціально-економічні аспекти поводження із побутовим и відходами, є психологічні аспекти, що стосуються мотивації людей організовувати власну поведінку належним чином. Поступово у соціумі, насамперед, у розвинених країнах, укорінюється переконання, що кожна людина здатна зробити свій внесок у скорочення побутових відходів: якщо оптимізує структуру свого споживання; мінімізує використання полімерної тари й упаковки, замінюючи їх більш "еко-дружніми" аналогами; якщо відповідально підходитиме до сортування власних відходів. До того ж і сама держава у таких країнах вдається до фінансового стимулювання екологічно-відповідальної поведінки своїх громадян, а також компаній і підприємств, встановлюючи певні податкові та комунальні пільги для тих, хто зменшує генерацію побутових відходів і сумлінно ставиться до їхнього сортування. Один 3 головних принципів системи поводження 3 відходами збирати й сортувати сміття потрібно на самому ранньому етапі, якомога ближче до джерела його утворення. При цьому, серед найважливіших досягнень урядів і муніципальної влади у справі поводження 3 відходами в розвинених країнах, можна назвати те, що їм вдалося привчити абсолютну більшість своїх громадян до думки про необхідність самостійного сортування побутових відходів. Комбінація принципу економічної вигоди від раціонального поводження із відходами, та символічного, однак вельми значущого для людей ефекту причетності до регіонального екологічного благополуччя, - одна 3 ключових передумов зменшення засміченості територій та підвищення якості життя людства.

Ключові слова: фрілософрія споживання; соціальна екологія; мегаполіс; еко-дружня свідомість; перероблення побутових відходів; утилізація; рециклінг.

(C) Oleksandr Stovpets

Надійшла до редакції: 22.01.2020

Прийнята до друку: 10.02.2020 